\title{
Culture as a Javanese Language Retention Strategy for Women's Society in Klaten, Central Java
}

\author{
Suharyo* \\ Indonesian Literature Department, Faculty of Humanities, Diponegoro University, Indonesia
}

\begin{abstract}
Women are the key to language retention. On the other hand, language is closely related to culture. Then, how can women and their culture maintain their language (read: Javanese)? To discuss this, this paper uses observation, interviews, and questionnaires. The result was, (1) Javanese Krama began to be threatened, both in urban and rural societies in Klaten, (2) Indonesian had begun to urge the existence of Javanese, (3) Javanese Ngoko was still maintained even though the percentage was not too high (under 65\%), (4) percentage of language retention in urban women in Klaten, is still relatively better than in rural communities, (5) Javanese language retention strategies are carried out through religious lectures, alms earth traditions, and nyadran (a term for pilgrimage and cleaning the grave).
\end{abstract}

\section{Introduction}

One of the essential cultural elements is language. Language can be a sign that living things are said to be human because they have language. Because, other living creatures "do not have" language, so humans are often interpreted as "animals that have a system of symbols/signs" (animal symbolism). It is also through language that culture in a society can be known, recognized, internalized, and passed on. Without language, it is difficult to imagine what culture is. In addition to language as one of the cultural elements, another element is a system of ideas. The system of ideas is in the collective memory of the community (the owner of that culture). The system of ideas is abstract and can be recognized when it manifests in an action/behavior. One of the behaviors that can be identified to uncover the ideas behind it is language behavior. One example of language behavior in this paper is the behavior in speaking Javanese.

The language behavior observed in this paper is the behavior of women society in Klaten, Central Java. The reason why women are the subject of discussion is that women are the central point in the life of a society. Many expressions show the majesty and elegance of women. Examples of grandeur and/or "worship" of women recorded in the vocabulary (culture) is surga berada di telapak kaki Ibu (heaven is in the soles of the mother), Ibu pertiwi (motherland), Ibu negara (first Lady), Ibu kota (capital city), Ibu jari

* Corresponding author: haryo.sastra@gmail.com 
(thumb), and Dewi Sri (Goddess Sri). Women's elegance is often symbolized through expressions/proverbs, such as kulitnya halus bagai sutera (skin as smooth as silk), matanya bagai bintang kejora (eyes like a Morning Star), pipinya bagai delima merekah (cheeks as red as pomegranates), alisnya bagai semut beriring (eyebrows as neat as ants trooped).

Furthermore, Sibarani [1] illustrates language and culture that are related to the nature of culture, cultural elements, and cultural patterns of behavior as presented below.

Table 2. Nature of Culture, Cultural Elements, and Cultural Patterns of Behavior

\begin{tabular}{|c|c|c|c|}
\hline NO & $\begin{array}{l}\text { THE NATURE } \\
\text { CULTURE }\end{array}$ & $\begin{array}{l}\text { CULTURAL } \\
\text { ELEMENTS }\end{array}$ & $\begin{array}{l}\text { CULTURAL } \\
\text { PATTERNS } \\
\text { BEHAVIOR }\end{array}$ \\
\hline 1 & $\begin{array}{l}\text { Habits that are described } \\
\text { through the biological, } \\
\text { environmental, } \\
\text { psychological, and } \\
\text { historical components of } \\
\text { human existence. }\end{array}$ & Language & $\begin{array}{l}\text { Derived from the human } \\
\text { mind }\end{array}$ \\
\hline 2 & $\begin{array}{l}\text { Obtained and inherited } \\
\text { socially through the } \\
\text { learning process }\end{array}$ & Knowledge system & $\begin{array}{l}\text { Provides ease in the } \\
\text { interaction between the } \\
\text { environment and humans }\end{array}$ \\
\hline 3 & Structured & Social organization & $\begin{array}{l}\text { Fulfill basic human } \\
\text { needs }\end{array}$ \\
\hline 4 & $\begin{array}{l}\text { Divided into aspects or } \\
\text { elements }\end{array}$ & Living equipment system & $\begin{array}{l}\text { Cumulative and } \\
\text { adaptation to external } \\
\text { and internal conditions }\end{array}$ \\
\hline 5 & Dynamic & Livelihood system & $\begin{array}{l}\text { Tends to form a } \\
\text { consistent structure }\end{array}$ \\
\hline 6 & Diverse & Religious & $\begin{array}{l}\text { Learned and shared by } \\
\text { society members }\end{array}$ \\
\hline 7 & Relative & Art & $\begin{array}{l}\text { Transmitted to a new } \\
\text { generation }\end{array}$ \\
\hline
\end{tabular}

Lately, many people are worried about the existence and sustainability of regional languages in general and Javanese in particular. Many experts and practitioners in various forums expressed their concern about how the present and future conditions deal with the sustainability of local languages, one of which is Javanese. It is feared that Javanese will be left behind by the speakers. If that happens, Javanese language will only become a cultural artifact scattered in linguistic works (horoscope, magazines, newspapers) which are "only" found in libraries and alienated from their speakers.

The concern of experts and/or practitioners is not without reason, considering that in daily practice if observed, almost all Javanese people have used Indonesian more often than using Javanese, let alone Javanese krama. Suharyo [2-3] confirm these concerns. Other findings ...

Is it true that Javanese will be displaced and/or extinct? If all Javanese people still believe and take care of their culture, surely the Javanese language will still exist. On the contrary, it will be displaced and even endangered when the Javanese people no longer believe in practice, and nguri-uri (preserve) their culture. This paper tries to explain it based on the results of the research that the writer has done. For this purpose, the writer made observations on the Klaten society, interviews with female leaders (arts, religion, education, 
society), and distributed questionnaires to several female respondents in Klaten, Central Java.

\section{Results and Discussion}

No different from the two previous districts studied by the writter, in Klaten district, the observation points also covered urban and rural areas. The results of data analysis in the city of Klaten are presented in the following graph 1.

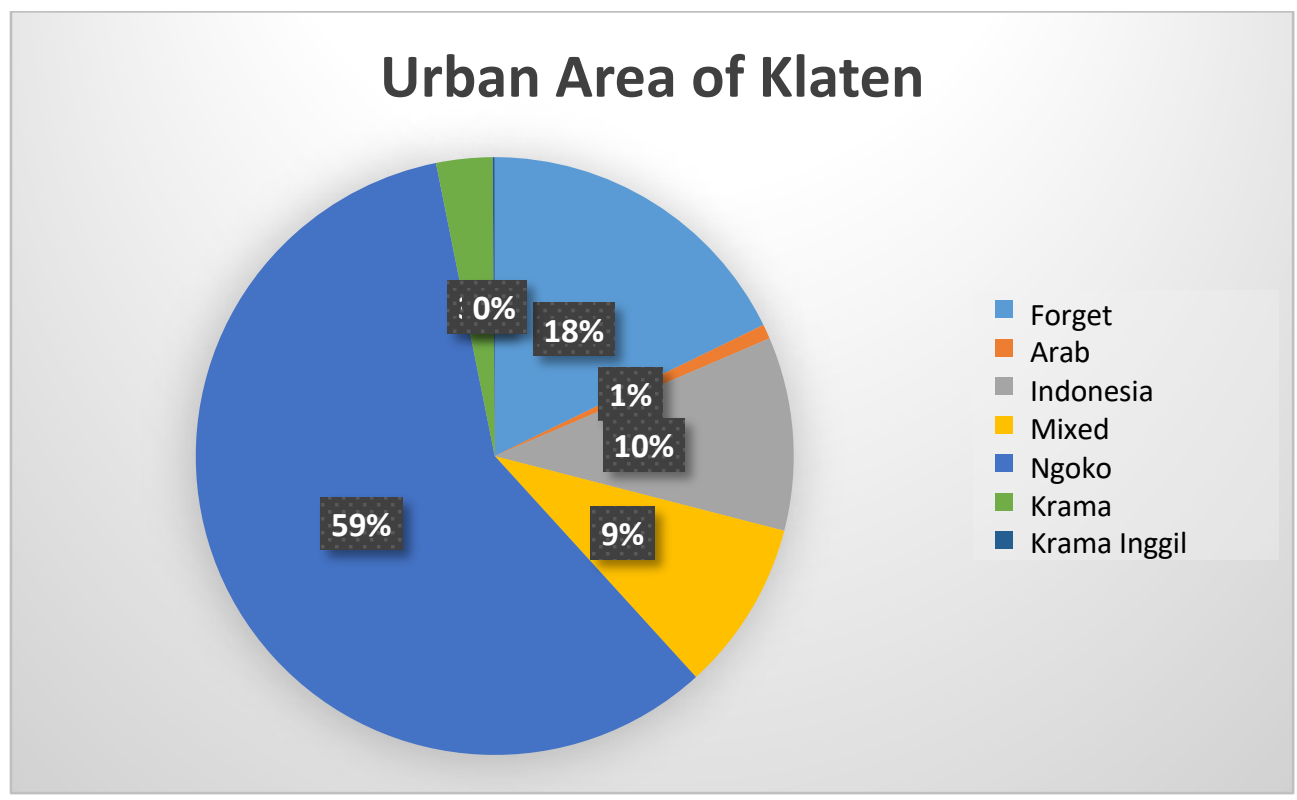

Figure 1. Graph of Selection Patterns and Javanese Language Retention Models in Urban Areas in Klaten

Based on the results of data collection in urban areas in Klaten, data obtained that as many as $59 \%$ of women answered using Ngoko Javanese more frequently, then as many as $18 \%$ of women answered forgetting or never using Javanese in daily life, as many as $10 \%$ of people women answered using Indonesian in daily life, 9\% of women use mixed languages, $7 \%$ of women also use mixed languages, $3 \%$ of women use Krama Javanese, 1\% of women use Arabic, and as many as $0 \%$ of women use the Krama Inggil Javanese.

Based on in-depth interviews with Mrs. Sumiyati, as a religious and educational figure, it was revealed that the society, especially women in Klaten, still highly upholds Javanese language and culture, so that the Javanese language still exists in this area. But due to the large number of migrants from outside the Klaten area (outside the provinces and islands), it did not rule out the possibility that the existence of Javanese began to be endangered. Therefore, strategic steps are needed in the effort to maintain Javanese. From this interview, it was also found that there were some efforts to maintain the Javanese language in this area. One of them is through the use of Javanese in religious activities. This is what later became an important point for Mrs. Sumiyati in her efforts to maintain Javanese, considering that Mrs. Sumiyati was also a preacher. Besides using religious channels, they also used artistic channels in Klaten, for example, Ketoprak. Other ways are through traditional channels, such as almsgiving and exemplary way (through public or religious figures). 
For the results of data analysis in the rural area in Klaten, the findings are presented in Figure 2 below.

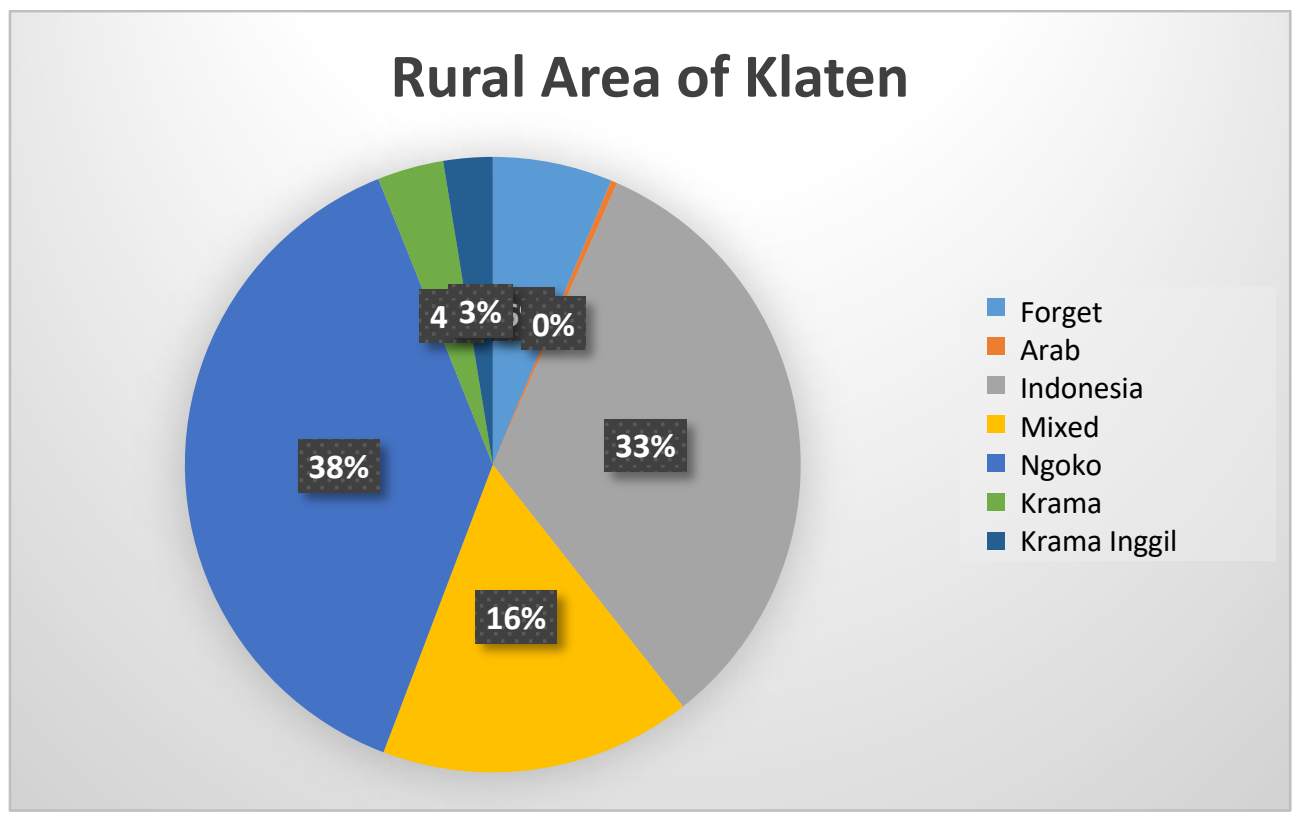

Figure 2. Patterns of Selection and Model of Javanese Language Retention in Rural Areas in Klaten

Based on the results of data analysis in the rural areas in Klaten, $38 \%$ of women use Javanese Ngoko, then $33 \%$ of women use Indonesian, $16 \%$ of women use mixed languages, $6 \%$ of women answer that they forget or never use Javanese, as much as $4 \%$ of women use Javanese Krama, as much as 3\% of women use Javanese Krama Inggil, and as much as $0 \%$ of women use Arabic.

Based on the results of in-depth interviews with Mrs. Muhimatul as a religious figure, it can be concluded that the existence of Javanese has begun to erode. Although the Javanese language is still widely used in cultural events such as almsgiving and religious events such as lectures and nyadran (pilgrimage), Javanese is not fully used in these events. Of the three events, only nyadran (pilgrimage) still fully uses Javanese. Also, the majority of people still use mixed languages depending on who is the interlocutor.

\section{Conclusion}

From the description above, it appears that the use of Javanese Krama has a tiny percentage. That is, the existence of Javanese Krama in Klaten is threatened. The existence of Javanese in the urban areas of Klaten is relatively better compared to the rural areas in Klaten. It seems that women in rural areas are experiencing vertical mobility. Therefore, women in urban areas in Klaten maintain Javanese relatively better than women in rural areas. Apart from that, the two urban and rural societies in Klaten try to maintain Javanese through cultural ways, such as almsgiving, religious activities, and nyadran (pilgrimage) traditions. 


\section{References}

1. Sibarani, Robert,2004, Antroplogi linguistic, Medan: peneerbit Moda

2. Suharyo, 2017. Pemilihan kode pada generasi mudan non-jawa dalam Nusa, vol.12, No,4, November 2017

3. 2018, Nasib bahasa Jawa adan bahasa Indonesia dalam pandangan dan sikap bahasa generasi muda jawa, dalam Nusa, vol.13, no.2, mei 2018 